\title{
PENERAPAN MODEL PEMBELAJARAN COOPERATIVE SCRIPT UNTUK MENINGKATKAN KEAKTIFAN DAN HASIL BELAJAR SISWA
}

\author{
(Studi Kasus pada Siswa Kelas X IPS 1 di SMA Negeri 4 Jember Mata Pelajaran Ekonomi \\ Kompetensi Dasar Mendeskripsikan Perkoperasian dalam Perekonomian Indonesia Semester \\ Genap Tahun Ajaran 2017/2018)
}

\author{
Qonit Darojat ${ }^{1}$, Hety Mustika Ani' ${ }^{1}$, Bambang Suyadi ${ }^{1}$ \\ ${ }^{1}$ Program Studi Pendidikan Ekonomi, Fakultas Keguruan dan Ilmu Pendidikan, Universitas Jember \\ e-mail: qonit.33@gmail.com
}

\begin{abstract}
Abstrak
Penelitian ini bertujuan untuk mendeskripsikan penerapan model pembelajaran Cooperative Script dalam meningkatkan keaktifan dan hasil belajar siswa kelas X IPS 1 SMA Negeri 4 Jember kompetensi dasar mendeskripsikan perkoperasian dalam perekonomian Indonesia semester genap tahun ajaran 2017/2018, serta mengetahui peningkatan keaktifan dan hasil belajar siswa kelas X IPS 1 SMA Negeri 4 Jember. Penelitian ini merupakan penelitian tindakan kelas yang dilaksanakan dengan 2 siklus yang terdiri dari beberapa tahapan yaitu, perencanaan, pelaksanaan tindakan, observasi, dan refleksi. Metode pengumpulan data yang digunakan adalah observasi, tes, wawancara, dan dokumen. Penelitian ini menggunakan analisis data secara deskriptif dengan pendekatan kualitatif yaitu memaparkan data yang diperoleh peneliti dari hasil pelaksanaan tindakan. Hasil penelitian ini menunjukkan bahwa dengan menerapkan model pembelajaran Cooperative Script dapat meningkatkan keaktifan dan hasil belajar siswa kelas X IPS 1 SMA Negeri 4 Jember pada mata pelajaran ekonomi kompetensi dasar mendeskripsikan perkoperasian dalam perekonomian Indonesia semester genap tahun ajaran 2017/2018. Pada siklus I keaktifan belajar siswa dalam kategori sedang yaitu 2,8 meningkat menjadi 3,6 kategori tinggi pada siklus II. Sedangkan, hasil belajar siswa pada siklus I nilai rata-rata siswa 78,5 dan ketuntasan belajar secara klasikal 79,41\%. Pada siklus II mengalami peningkatan nilai rata-rata siswa menjadi 86,3 dan ketuntasan belajar secara klasikal 91,17\%.
\end{abstract}

Kata Kunci: Model Pembelajaran Cooperative Script, Keaktifan, Hasil Belajar

\section{PENDAHULUAN}

Pendidikan menjadi salah satu faktor yang penting dalam perkembangan suatu negara. Kualitas pendidikan salah satunya dipengaruhi saat proses pembelajaran berlangsung. Implementasi kurikulum 2013 dalam proses pembelajaran menuntut siswa untuk telibat aktif, kreatif, inovatif dan efektif melalui penguatan sikap, keterampilan dan pengetahuan. Siswa dalam proses pembelajaran berkembang menjadi siswa yang aktif, membangun pengetahuan dan keterampilan baru berdasar pengetahuan dan keterampilan yang dikuasai. Sedangkan Peran guru sesuai kurikulum 2013 adalah melakukan pembelajaran aktif yang berpusat pada siswa. Oleh karena itu dalam proses pembelajaran guru harus dapat memilih model-model pembelajaran agar dapat menimbulkan komunikasi aktif antara guru dan siswa. Penggunaan model pembelajaran merupakan salah satu strategi yang digunakan guru untuk meningkatkan keaktifan dan hasil belajar siswa.

Berdasarkan informasi yang diberikan guru mata pelajaran ekonomi kelas X IPS 1 di SMA Negeri 4 Jember bahwa kegiatan pembelajaran masih didominasi oleh metode ceramah dan penugasan. Penerapan diskusi kelompok jarang diterapkan pada saat proses pembelajaran berlangsung. Guru menerapkan model pembelajaran konvensional misalnya dengan membentuk kelompok sesuai urutan presensi atau dengan berhitung, kemudian siswa mulai berdiskusi dilanjutkan mempresentasikan hasil diskusi sampai pada kesimpulan. Proses diskusi kelompok yang monoton serta kurang bervariasi menjadikan proses pembelajaran kurang menarik dan kondusif sehingga akan berdampak pada keaktifan dan hasil belajar siswa.

Data hasil observasi menunjukkan bahwa skor rata-rata keaktifan belajar siswa kelas X IPS 1 mencapai 1,90 kategori rendah. Sehinggga kelas X IPS 1 menjadi kelas yang memiliki skor keaktifan lebih rendah dibandingkan dengan kelas X IPS 2. Berikut data tabel keaktifan belajar siswa kelas X IPS SMA Negeri 4 
Jember :

Tabel 1 Keaktifan Belajar Siswa Kelas X IPS Pada Mata Pelajaran Ekonomi

\begin{tabular}{cccc}
\hline Kelas & Jumlah siswa & Skor rata-rata keaktifan siswa & Kriteria \\
\hline X IPS 1 & 34 & 1,90 & Rendah \\
\hline X IPS 2 & 36 & 2,32 & Sedang \\
\hline
\end{tabular}

Sumber: Data hasil observasi keaktifan belajar siswa kelas X IPS

Berdasarkan tabel diatas rendahnya keaktifan belajar siswa kelas X IPS 1 terlihat pada saat proses pembelajaran berlangsung, sikap siswa kurang aktif ditunjukkan dengan banyaknya siswa yang kurang memperhatikan guru saat menerangkan pelajaran. Ketika guru memberikan kesempatan siswa untuk bertanya hanya satu dua siswa yang berani bertanya. Pada saat diskusi kelompok terlihat banyak siswa yang kurang aktif maupun kurang berkontribusi terhadap kelompoknya, terdapat siswa kurang semangat dan mengantuk pada saat proses diskusi berlangsung. Kurangnya keaktifan siswa saat proses pembelajaran berdampak pada hasil belajar siswa rendah sehingga tujuan pembelajaran tidak tercapai.

Data hasil belajar siswa kelas X IPS SMA Negeri 4 Jember menunjukkan bahwa kelas X IPS 1 memiliki hasil belajar yang tergolong rendah dibandingkan kelas X IPS 2. Rendahnya hasil belajar siswa pada mata pelajaran ekonomi dapat dilihat pada tabel berikut :

Tabel 2 Hasil Belajar Siswa Kelas X IPS KD Sebelumnya

\begin{tabular}{lccc}
\hline Kelas & Jumlah Siswa & Nilai rata-rata & Ketuntasan Klasikal \\
\hline X IPS 1 & 34 & 66,4 & $41,17 \%$ \\
\hline X IPS 2 & 36 & 73,6 & $55,55 \%$
\end{tabular}

Sumber: Daftar nilai guru mata pelajaran Ekonomi SMAN 4 Jember

Berdasarkan data diatas rata-rata hasil ulangan harian siswa kelas X IPS 1 materi sebelumnya yaitu sebesar 66,4 dengan ketuntasan klasikal siswa kelas X IPS 1 sebesar 41,17\%. Hasil belajar semua kelas masih belum memenuhi Kriteria Ketuntasan Minimal (KKM) yakni $\geq 77$ dan ketuntasan klasikal masih dibawah $\geq 77 \%$.

Berdasarkan data diatas guru dan peneliti sepakat memilih salah satu kelas untuk dilakukan perbaikan yaitu kelas X IPS 1. Terkait permasalahan diatas peneliti bersama guru mata pelajaran ekonomi kelas X IPS SMA Negeri 4 Jember melakukan perbaikan pembelajaran dikelas dengan menerapkan model pembelajaran Cooperative Script pada kompetensi dasar mendeskripsikan perkoperasian dalam perekonomian Indonesia.

Model pembelajaran Cooperative Script merupakan salah satu bentuk model pembelajaran kooperatif. Pada pembelajaran Cooperative Script terjadi kesepakatan antara siswa tentang aturan-aturan dalam berkolaborasi, yaitu siswa satu dengan yang lainnya bersepakat untuk menjalankan peran masing-masing. Siswa yang berperan menjadi pembicara membacakan hasil pemecahan yang diperoleh beserta prosedurnya dan siswa yang menjadi pendengar, menyimak dan mendengar penjelasan dari pembicara jika ada kesalahan dari pembicara serta mengingatkan pembicara jika ada kesalahan. Masalah dipecahkan bersama untuk kemudian disimpulkan bersama. Sementara antara guru dan siswa, yaitu peran sebagai fasilitator yang mengarahkan siswa untuk mencapai tujuan belajar. Selain itu, guru mengontrol selama pembelajaran berlangsung dan guru mengarahkan siswa jika merasa kesulitan. Pada interaksi siswa terjadi kesepakatan, diskusi, dan menyampaikan pendapat dari ide-ide pokok materi, saling mengingatkan dari kesalahan konsep yang disimpulkan dan membuat kesimpulan bersama. Interaksi belajar yang terjadi benar-benar interkasi dominan siswa dengan siswa (Shoimin,2014:50).

Model pembelajaran Cooperative Script diharapkan sesuai jika diterapkan pada Kompetensi dasar mendeskripsikan perkoperasian dalam perekonomian Indonesia. Materi kompetensi dasar mendeskripsikan perkoperasian dalam perekonomian Indonesia merupakan salah satu materi yang erat hubungannya dengan kehidupan sehari-hari. Untuk itu perlu model pembelajaran yang sesuai untuk diterapkan dalam proses pembelajaran agar siswa dapat menguasai materi secara keseluruhan, siswa lebih berpartisipasi secara aktif dalam belajar, menimbulkan suasana belajar yang lebih kondusif, menyenangkan, serta hasil belajar dapat meningkat dan tujuan pembelajaranpun tercapai.

Berdasarkan latar belakang tersebut peneliti bersama guru akan melakukan perbaikan dalam proses 
pembelajaran dengan diadakan penelitian tindakan kelas yang berjudul "Penerapan Model Pembelajaran Cooperative Script untuk Meningkatkan Keaktifan dan Hasil Belajar Siswa (Studi Kasus pada Siswa Kelas X IPS 1 di SMA Negeri 4 Jember Mata Pelajaran Ekonomi Kompetensi Dasar Mendeskripsikan Perkoperasian dalam Perekonomian Indonesia Semester Genap Tahun Ajaran 2017/2018)".

\section{METODE}

Penelitian ini dilakukan pada tanggal 28 Februari-15 Maret 2018. Subyek penelitian ini seluruh siswa kelas X IPS 1 yang berjumlah 34 siswa terdiri dari 18 siswa laki-laki dan 16 siswi perempuan. Penelitian ini menggunakan analisis data secara deskriptif dengan pendekatan kualitatif yaitu memaparkan data yang diperoleh peneliti dari hasil pelaksanaan tindakan. Metode pengumpulan data yang digunakan adalah observasi, tes, wawancara, dan dokumen. Analisis data yang akan digunakan yaitu analisis data keaktifan belajar Siswa, analisis data hasil belajar siswa dan analisis data hasil observasi guru.

\section{HASIL DAN PEMBAHASAN}

\section{Hasil Penelitian}

Hasil observasi selama proses pembelajaran pada siklus I menunjukkan keaktifan siswa masih dalam kategori sedang. Hal ini disebabkan ada beberapa langkah pembelajaran yang belum terlaksana secara optimal seperti guru kurang memotivasi siswa serta penjelasan model pembelajaran Cooperative Script perlu dijelaskan lagi pada pertemuan selanjutnya, selain itu masih ada beberapa siswa yang berbicara tidak berkaitan dengan materi. Kekurangan yang terjadi pada siklus I dilakukan perbaikan pada siklus II dan hasilnya terjadi peningkatan pada keaktifan belajar siswa yang meningkat dari sedang menjadi tinggi.

Peningkatan keaktifan belajar siswa dari siklus I pada siklus II dapat dilihat pada tabel berikut : Tabel 3 Peningkatan Keaktifan Belajar Siswa Siklus 1 Pada Siklus II

\begin{tabular}{lcc}
\hline Siklus & Skor rata-rata keaktifan siswa & Kategori \\
& & \\
\hline Sikus I & 2,8 & Sedang \\
\hline Siklus II & 3,6 & Tinggi \\
\hline Sumber : Data Primer yang diolah & \\
Dari tabel diatas dapat dilihat bahwa terjadi peningkatan pada keaktifan belajar siswa dari siklus I sebesar \\
2,8 dengan kategori sedang, meningkat pada siklus II menjadi 3,6 dengan kategori aktif meningkat sebesar 0,8. \\
$\begin{array}{l}\text { Peningkatan paling tinggi terjadi pada indikator berusaha mencari berbagai informasi yang diperlukan untuk } \\
\text { pemecahan masalah, disebabkan siswa berusaha mencari informasi terkait }\end{array}$ \\
$\begin{array}{l}\text { sumber.Peningkatan keaktifan belajar siswa juga dapat dilihat pada grafik berikut : } \\
\text { berbagai }\end{array}$
\end{tabular}




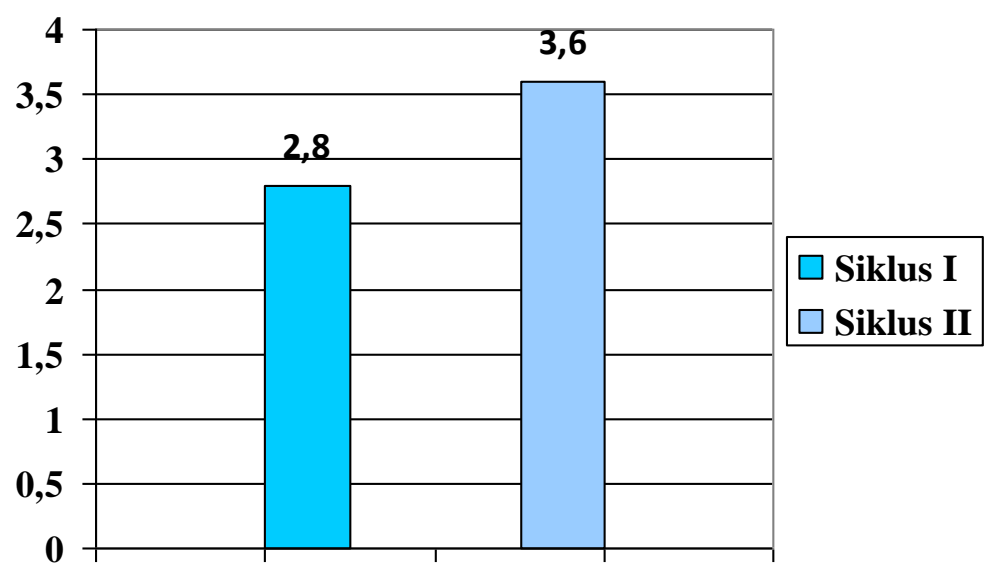

Siklus I Siklus II

Gambar 1 Peningkatan Keaktifan Siswa Siklus I pada Siklus II

Berdasarkan tabel dan gambar diatas menunjukkan bahwa keaktifan belajar siswa terjadi peningkatan dari siklus I ke siklus II. Pada siklus I skor keaktifan belajar siswa sebesar 2,8 sedangkan pada siklus II mengalami peningkatan menjadi 3,6. Peningkatan skor keaktifan belajar siswa dari siklus I ke siklus II sebesar 0,80 .

Peningkatan keaktifan belajar siswa juga sejalan dengan peningkatan hasil belajar siswa. Peningkatan hasil belajar siswa dari siklus I ke siklus II dapat dilihat pada tabel berikut :

Tabel 4 Peningkatan Hasil Belajar Siswa kelas X IPS 1 Siklus I pada Siklus II

Siklus

Jumlah siswa

Nilai rata-rata

Ketuntasan klasikal siswa

\begin{tabular}{cccc}
\hline I & 34 & 78,5 & $79,41 \%$ \\
\hline II & 34 & 86,3 & $91,17 \%$ \\
\hline
\end{tabular}

Sumber : Data primer yang diolah

Pada tabel diatas dapat dilihat bahwa terjadi peningkatan pada hasil belajar siswa. Peningkatan nilai ratarata siswa yakni dari 78,5 meningkat menjadi 86,3 , terjadi peningkatan sebesar 7,76. Sedangkan peningkatan ketuntasan klasikal dari siklus I ke siklus 2 dapat dilihat dalam grafik berikut :

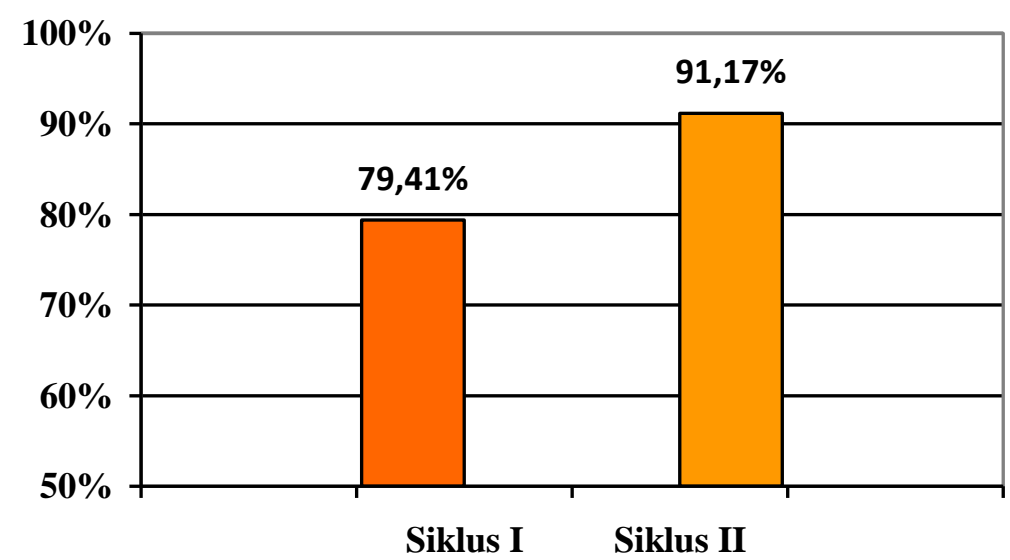

Gambar 2 Peningkatan Ketuntasan Klasikal Hasil Belajar Siswa Siklus I dan Siklus II

Berdasarkan gambar diatas dapat dilihat bahwa ketuntasan belajar siswa secara klasikal mengalami 
peningkatan dari siklus I ke siklus II. Peningkatan tersebut terlihat dari siklus I sebesar 79,41\% dan siklus II sebesar $91,17 \%$, terjadi peningkatan sebesar $11,76 \%$. Hasil belajar siswa yang diperoleh menunjukkan bahwa target penelitian telah tercapai meskipun tidak $100 \%$.

\section{Pembahasan}

Hasil penelitian menunjukkan bahwa penerapan model pembelajaran Cooperative Script dalam proses pembelajaran dikelas X IPS 1 SMA Negeri 4 Jember pada mata pelajaran ekonomi kompetensi dasar mendeskripsikan perkoperasian dalam perekonomian Indonesia semester genap tahun ajaran 2017/2018 dapat meningkatkan keaktifan dan hasil belajar siswa. Hal ini dapat dilihat dari hasil observasi awal keaktifan siswa masih tergolong rendah dan rata-rata hasil belajar secara klasikal masih belum tuntas atau belum mencapai KKM. Setelah dilakukan perbaikan dengan menerapkan model pembelajaran Cooperative Script keaktifan dan hasil belajar siswa mengalami peningkatan dari siklus I ke siklus II.

Pada penerapan model pembelajaran Cooperative Script guru membagi siswa untuk berpasangan, kemudian guru membagikan wacana /materi kepada masing-masing siswa untuk dibaca dan membuat ringkasan,dalam hal ini siswa diberi kesempatan untuk bertanya, kemudian guru dan siswa menetapkan siapa yang pertama berperan sebagai pembicara dan siapa yang berperan sebagai pendengar, sesuai kesepakatan siswa yang menjadi pembicara membacakan ringkasan atau prosedur pemecahan masalah selengkap mungkin dengan memasukkan ide-ide pokok dalam ringkasan dan pemecahan masalahnya. Sementara pendengar (a) menyimak/mengoreksi/menunjukkan ide-ide pokok yang kurang lengkap; (b) membantu mengingat /menghafal ide-ide pokok dengan menghubungkan materi sebelumnya atau dengan materi lainnya, setelah itu yang semula sebagai pembicara ditukar menjadi pendengar dan sebaliknya serta dilakukan seperti diatas, selajutnya guru bersama siswa membuat kesimpulan.

Selama proses pembelajaran siswa lebih aktif dan antusias dalam mengikuti pembelajaran. Hal tersebut dapat dilihat dari hasil observasi keaktifan siswa mengalami peningkatan pada tiap siklus. Pada siklus I, keaktifan belajar siswa masih dalam kategori sedang dengan skor 2,8 kemudian dilakukan perbaikan pada siklus II sehingga terjadi peningkatan sebesar 0,80 dengan skor 3,6 dalam kategori aktif. Dalam hal ini guru sudah melakukan kegiatan pembelajaran dengan baik dan optimal sesuai dengan rencana perbaikan pembelajaran yang telah disusun.

Peningkatan keaktifan siswa tersebut dapat dilihat dari tiap pertemuan siswa mulai aktif bertanya dan mengemukakan pendapatnya. Siswa juga aktif menanggapi pertanyaan baik dari guru maupun siswa lain. Pada saat diskusi siswa berusaha mencari informasi dari berbagai sumber dan berpartisi dalam kelompok diskusinya. Sebagaimana teori menurut Brosseau (dalam Hadi 2007:18) menjelaskan bahwa proses pembelajaran pada Cooperative Script adanya kotrak belajar yang eksplisit antara guru dengan siswa dan siswa dengan siswa mengenai cara-cara berkolaborasi. Siswa bersama dengan pasangannya memecahkan masalah secara bersamasama. Siswa dituntut untuk beraktivitas sendiri, siswa menemukan sendiri suatu konsep atau mampu memecahkan masalah sendiri.

Model pembelajaran Cooperative Script memiliki kelebihan-kelebihan Menurut Huda (2013:214) yaitu dapat menumbuhkan ide-ide atau gagasan baru, mendorong siswa untuk berlatih memecahkan masalah dengan mengungkapkan idenya secara verbal dan membandingkan ide siswa dengan ide temannya, membantu siswa belajar menghormati dan menerima perbedaan yang ada. Pernyataan guru ekonomi kelas X IPS 1 juga menjelaskan bahwa keaktifan siswa semakin meningkat yakni :

“...model Cooperative Script sangat mudah diterapkan dikelas, Model pembelajaran ini membuat semua siswa mendapat giliran peran sebagai pendengar dan pembicara, saya senang melihat siswa antusias dalam belajar, mereka terlihat aktif saat diskusi dan mulai berani mengemukakan pendapatnya.” (Bu.YSR, 45Th).

Siswa juga menyampaikan hal yang serupa ketika diwawancarai mengenai keaktifannya dikelas :

“...saya senang dengan model pembelajaran ini, saya bergatian mendapat peran pembicara dan pendengar, saya merasa lebih aktif pada saat diskusi. Saya tidak malu untuk berpendapat dan bertanya kepada guru dan juga teman yang lain." (IP, 16th).

Keaktifan siswa meningkat disebabkan penerapan model pembelajaran Cooperative Script berjalan dengan baik dan optimal. Model pembelajaran Cooperative Script secara tidak langsung terdapat kontrak 
belajar antara guru dengan siswa dan siswa dengan siswa mengenai cara berkolaborasi. Siswa juga dilatih untuk saling bekerja sama satu sama lain dalam suasana yang menyenangkan.

Selain meningkatkan keaktifan, penerapan model pembelajaran Cooperative Script juga meningkatkan hasil belajar siswa. Peningkatan hasil belajar siswa dapat dilihat dari sebelum menerapkan model pembelajaran Cooperative Script nilai rata-rata siswa 66,38, dan ketuntasan klasikal sebesar $41,17 \%$. Hasil belajar pada siklus I, secara klasikal ketuntasan hasil belajar siswa sudah mencapai KKM yakni 79,41\% . dari 34 siswa, 27 siswa hasil belajarnya tuntas dan 7 siswa hasil belajarnya belum tuntas. Pada siklus II hasil belajar secara klasikal meningkat sebesar 91,17\%. Dari data analisis tersebut penerapan model pembelajaran Cooperative Script pada kompetensi dasar mendeskripsikan perkoperasian dalam perekonomian Indonesia dapat meningkatkan keaktifan dan hasil belajar siswa kelas X IPS 1 SMA Negeri 4 Jember.

Peningkatan hasil belajar siswa disebabkan dengan diterapkannya model pembelajaran Cooperative Script. Dengan diterapkannya model pembelajaran ini siswa terlibat langsung dengan materi yang dipelajarinya sehingga siswa akan mudah mengingat apa yang mereka pelajari. Selain itu siswa lebih percaya lagi pada kemampuan sendiri untuk berpikir, mencari informasi dari sumber lain, dan belajar dari siswa lain. Siswa juga berlatih memecahkan masalah dengan mengungkapkan idenya secara verbal dan membandingkan ide siswa dengan ide temannya sehingga memudahkan siswa untuk menguasai materi secara optimal. Hal tersebut memudahkan siswa dalam mengerjakan soal ulangan harian. Sebagai mana pendapat Brousseau (dalam Shoimin 2014:49) menyatakan bahwa model pembelajaran Cooperative Script secara tidak langsung terdapat kontrak belajar antara guru dengan siswa dan siswa dengan siswa mengenai cara berkolaborasi. Hal ini juga diungkapkan guru ekonomi X IPS 1 saat wawancara.

“...dengan menerapkan model pembelajaran Cooperative Script, seluruh siswa lebih cepat menguasai materi, mereka mencatat point-point yang belum mereka pahami dengan saling berganti peran. Sehingga pada saat ualangan harian mereka mampu menguasai materi dan menjawab soal dengan mudah hasil belajarpun juga tuntas mencapai KKM.” (Bu YSR, 45th)

Selain guru, siswa juga menyampaikan hal serupa terkait hasil belaajrnya ketika diwawancara. Hal ini sebagaimana ungkapan siswa :

“...Pada saat pembelajaran suasananya menyenangkan, saya lebih mudah memahami materinya karena saya sudah meringkas point-point yang penting sehingga saya lebih mudah untuk mengingat materi. Nilai ulangan harian saya bagus 84 , biasanya saya remidi tapi seakarang tidak remidi lagi." (KST, 16Th)

Penerapan model pembelajaran Cooperative Script diterapkan dengan baik oleh guru dan tidak ada kesulitan dalam penerapannya. Observasi guru dalam menerapkan model pembelajaran Cooperative Script meningkat pada tiap pertemuan. Meskipun ada beberapa langkah pembelajaran yang masih terlewatkan pada siklus I seperti guru kurang memberikan mottivasi kepada siswa dan ada beberapa siswa yang belum aktif bertanya atau mengemukakan pendapat. Tetapi pada siklus II guru dalam menerapkan model pembelajaran sangat baik dan sudah memperbaiki kekurangan pada pertemuan sebelumnya.

Berdasarkan pembahasan diatas, dapat disimpulkan bahwa penerapan model pembelajaran Cooperative Script dapat meningkatkan keaktifan dan hasil belajar siswa kelas X IPS 1 SMA Negeri 4 Jember pada mata pelajaran ekonomi kompetensi dasar perkoperasian dalam perekonomian Indonesia semester genap tahun pelajaran 2017/2018.

\section{PENUTUP}

Berdasarkan hasil penelitian dan hasil analisis data yang dilakukan dapat disimpulkan bahwa penerapan model pembelajaran Cooperative Script dapat meningkatkan keaktifan dan hasil belajar siswa kelas X IPS 1 SMA Negeri 4 Jember pada mata pelajaran ekonomi kompetensi dasar perkoperasian dalam perekonomian Indonesia semester genap tahun pelajaran 2017/2018. Kaktifan siswa sebelum diterapkan model pembelajaran Cooperative Script masih tergolong rendah, tetapi setelah diterapkan model pembelajaran Cooperative Script keaktifan siswa meningkat. Pada siklus I keaktifan siswa masih dalam kategori sedang dengan skor 2,8 kemudian dilakukan perbaikan pada siklus II sehingga terjadi peningkatan sebesar 0,80 dengan skor 3,6 dalam kategori aktif.

Hasil belajar siswa setelah diterapkan model pembelajaran Cooperative Script juga meningkat. Pada 
siklus I nilai rata-rata siswa sebesar 78,5 dengan ketuntasan klasikal sebesar 79.41\%. Meningkat pada siklus II nilai rata-rata siswa sebesar 86,3 dengan ketuntasan klasikal siswa sebesar 91,17\%.

\section{DAFTAR PUSTAKA}

Fathurrohman, M. 2015. Model-model Pembelajaran Inovatif. Yogyakarta : Ar-Ruzz Media Hadi, S. 2007. Metodologi Research. Yogyakarta : Universitas Gajah Mada

Huda, M. 2013. Model-model Pengajaran dan Pembelajaran Isu-isu Metodis dan Paradigmatis. Yogyakarta : Pustaka Pelajar

Rusman. 2012. Model-Model Pembelajaran Mengembangkan Profesionalisme guru. Jakarta : Rajawali Pers Shoimin, Aris. 2014. 68 Model Pembelajaran Inovatif dalam Kurikulum 2013. Yogyakarta : Ar-Ruzz Media 